\title{
Pensioenverzekering? : een financieel-economische beschouwing
}

Citation for published version (APA):

Wolff, C. C. P. (1989). Pensioenverzekering? : een financieel-economische beschouwing. Van Gorcum. https://doi.org/10.26481/spe.19891110cw

Document status and date:

Published: 10/11/1989

DOI:

$10.26481 / \mathrm{spe} .19891110 \mathrm{cw}$

Document Version:

Publisher's PDF, also known as Version of record

\section{Please check the document version of this publication:}

- A submitted manuscript is the version of the article upon submission and before peer-review. There can be important differences between the submitted version and the official published version of record.

People interested in the research are advised to contact the author for the final version of the publication, or visit the DOI to the publisher's website.

- The final author version and the galley proof are versions of the publication after peer review.

- The final published version features the final layout of the paper including the volume, issue and page numbers.

Link to publication

\footnotetext{
General rights rights.

- You may freely distribute the URL identifying the publication in the public portal. please follow below link for the End User Agreement:

www.umlib.nl/taverne-license

Take down policy

If you believe that this document breaches copyright please contact us at:

repository@maastrichtuniversity.nl

providing details and we will investigate your claim.
}

Copyright and moral rights for the publications made accessible in the public portal are retained by the authors and/or other copyright owners and it is a condition of accessing publications that users recognise and abide by the legal requirements associated with these

- Users may download and print one copy of any publication from the public portal for the purpose of private study or research.

- You may not further distribute the material or use it for any profit-making activity or commercial gain

If the publication is distributed under the terms of Article $25 \mathrm{fa}$ of the Dutch Copyright Act, indicated by the "Taverne" license above, 


\section{PENSIOENVERZEKERING?}

Een financieel-economische beschouwing

\section{Rede}

in verkorte vorm uitgesproken bij de aanvaarding van het ambt van gewoon hoogleraar Financieel Management en Financiële Markten aan de Rijksuniversiteit Limburg

op vrijdag 10 november 1989

door

Dr. C.C.P. Wolff, MBA

Van Gorcum, Assen/Maastricht 
Ale rechuen woorbehouden. Niets un deze nitgave mag worden verveelwoudigd, opgeslagen in een geautomatiseerd gegevensbestand, of openbaar gemaakt, in enge vorm of op enige wijze, zonder voorafgande schriftelike toestemming van de uitgever.

Voorzover het maken van kopieen uit deze uitgave is toegestaan op grond var artikel $16 \mathrm{~B}$ Auteurswet 1912, averenkomstig het Besluit van 20 juni 1974 , 5t.b. 471 , en artikel 17 Auteurswet 1912, dient men de daarvoor wettelijk ver schuldigde vergoedingen te voldoen aan de Stichting Reprarecht (Postbus 882, 1180 AW Amstelveen).

\section{CIP.GEGEVENG KONINKLIJKE BIBLIOTHEEK, DEN HAAG}

Wolle, C.C.P.

Pesioenverzekering? Een fünancieel economische beschouwing

C.C.P. Wolft - Assen/Maastrich, Van Gorcum

Inaugurale rede Maastricht.

ISBN 9023225066

SISO 379.3 UDC $369.544 / 56(043.5)$ NUGI 683

Trefw.: pensioenverzekeringen.

Layout en druk: Leiter-Nypels, Maastricht

"De geleerde had oog noch oor voor zijn omgeving. Met schoolse hand wierp hij een formule op het papier en trok daar zijn conclusies uit."

Marten Toonder, Zeg nu zelf..., De Bezige Bij, Amsterdam, 1975, p. 192. 


\title{
PENSIOENVERZEKERING?
}

\section{Een financieel-economische beschouwing}

\author{
Dr. C.C.P. Wolff, MBA
}

\section{Inleiding}

Eén wan de aantrekkelijke kanten van het ambt dat ik vandaag officieel aanvaard, is het feit dat directe opname plaatsvindt in een pensioenfonds dat gehouden is om mij bij mijn emeritaat een welvaartswast pensioen te verstrekken. "Dit pensioenfonds staat voor de taak om beschikbare middelen zodanig te beheren dat te allen tijde kan worden voldaan aan dergelijke pensioenverplichtingen uit beleggingsopbrengsten en uit premieontvangsten van werkgevers en werknemers.

Gezien vanuit de Financierings- en Beleggingsleer is dit een interessante materie, waarin beleggingsportefeuilles, rendementen op verschillende vermogenscategorieën, inflatiebestendigheid van beleggingen, failleringskansen en beleggingshorizonten een belangrijke rol spelen. De onderhavige problematiek is verre van eenvoudig, zelfs wanneer wij alleen de bedrijfseconomische aspecten beschouwen. Daarnaast is evenwel sprake van een aanzienlijke wisselwerking met de institutionele en maatschappelijke omgeving waarin pensioenfondsen opereren. Vele ministers, parlementariërs, vakbondsleiders, E.G.-commissarissen e.d. smeden met regelmaat plannen met betrekking tot het beheer van pensioengelden en, soms, met betrekking tot de annwending van beschikbare financiële middelen.

In mijn rede wil ik deze wisselwerking aan de orde stellen. Hierbij zal ik gebruik maken van elementen uit het beschikbare instrumentarium in de Financierings- en Beleggingsleer om belangrijke ontwikkelingen van enig commentaar te voorzien. Dat ik in dit verband af en toe zal moeten laveren tussen mijn eigen vakgebied en de Leer der Openbare Financiën, is geen verrassing tegen de achtergrond van de historische banden tussen de twee vakgebieden, die mijn collega-orator vanmiddag met $U$ zal bespreken. ${ }^{2}$

1. De Algemene Burgerlijke Pensioenwet regelt de pensioenen van burgerlijke ambtenaren en hun nabestaanden.

2. Zie Backhaus (1989). 


\section{Penstoenfoudsen en -verplichtingen}

In Nederland zijn circa waalhonderd ondernemings-, bedrijes- en beroepsensioenfondsen werkzatm. Daarnaast neemt het Algemeen Burgerlijk Pensioenfonds (ABP) een prominente plaats in krachtens de Algemene Burgerlike Pansioenwet. De omvang van deze fondsen is niet gering: te zamen beschikken zij over een belegd vermogen wan meer dan $f 350$ mid. Naar internationale maatstaven is dit niveau van gecumuleerde pensioenbesparingen zeer hoog. In absolute termen neemt Nederland, na de Verenigde Staten, Japan en het Verenigd Koninkrijk, een vierde plaats in. 3 Wanneer we het belegd vermogen relateren an het aantal inwoners, bezet ons land zelfs de eerste plaats op de ranglijst. Per Nederlander is door pensioenfondsen ca. 25.000 , - belegd. De bestaansgrond van pensioenfondsen ligt besloten in de verplichtingenzijde van de balans. Ter financiering van pensioenaanspraken wordt doorgaans het kapitaaldekkingsstelsel gehanteerd. 4 De beleggingsopbrengsten, pensioenpremies en eventuele overige baten vormen een vermogen dat toereikend dient te zijn om pensioenbetalingen te kunmen verrichten. Ten aanzien wan de bepaling van de précieze onvang van de pensioenaanspraken van een (gewezen) werknemer bestaan vele verschillende regelingen.5 In de meeste gevallen is sprake van een zogenaamde eindloonregeling op basis waarvan het bruto pensioen de AOW-uitkering, of eventuele andere sociale uitkeringen, aanvult tot maximaal ongeveer zeventig procent van het latst genoten bruto loon of salaris.

Na het bereiken van de pensioengerechtigde leeftijd is het merendeel der pensioenen waardevast (gekoppeld aan een prijsindex) of welvaartswast (gekoppeld aan een loonindex). ${ }^{6}$ Deze regelingen zijn voor de individuele pensioengerechtigde van groot belang, maar vormen een bron van zorgen voor pensioenfondsdirecties en -besturen. Een cruciale vraag in dit verband is hoe rendementen op beleggingen zich in een inflatoire periode verhouden tot procentuele mutaties in de loon- en prijsindices.

\section{Aftemming van de beleggingen op de pensioenverplichtingen}

In de Pensioen - en Spaarfondsenwet treffen we een kernachtig artikel aan dat voorschrijft dat belegging wan de daartoe beschikbare gelden wan een pensioenfonds op "solide" wijze dient te geschieden. 7 Wat onder "solide" moet wor-

3. Zie Van Der Meer (1989).

4. Dil in tegenstelling tot bijwoorbeeld de volkswerzekeringen AOW en AWW, warvoor het omslagstelsel wordt gehanteerd.

5. Zie Besseling en Scheepers (1981).

6. Wewatriswatheid is woor ABP-pensioenen wastgelegd in de Algemene Burgenlijke Pensioenwer.

7. Zic Artikel 14 van de Pensioen- en Sparrfondsenwet. 
den verstaan wordt niet nader aangegeven. In de praktijk interpreteren vele bedrijfs- en ondernemingspensioenfondsen het woord "solide" tegen de achtergrond van de verplichtingenstructuur. Volgens deze interpretatie zijn beleggingen solide wanneer zij zijn afgestemd op de verplichtingen van het desbetreffende fonds. De ABP-wet laat zelfs geen ruimte voor interpretatie:

\section{"De vaststelling van het beleggingsbeleid geschiedt uitsluitend in het belawg van het fonds (...) en de afstemming op de opbouw van de verplichtingen van her fonds".}

Algemene Burgenlijke Pensioenwet, Artikel L14, lid 2.

De afstemming van beleggingen op pensioenverplichtingen wordt waak aangeduid met de Angelsaksische term "matching". Deze problematiek stat sterk in de belangstelling in de pensioenwereld. ${ }^{8}$ Wetenschappelijk onderzoek op clit terrein is zeer recent ${ }^{9}$, maar enkele voorlopige conclusies zijn voldoende interessant om vanmiddag met $U$ te delen.

Bij de afstemming van beleggingen op verplichtingen wordt gepoogd om de kans dat pensioenverplichtingen nier kunnen worden nagekomen zoveel als mogelijk te reduceren. ${ }^{10}$ Er zijn in dit verband drie belangrijke factoren die het contante-waardeniveau van de verplichtingen beïnvloeden en waarmee rekening gehouden dient te worden bij de formulering van een adequaat beleggingsbeleid 11 :

a. de ontwikkeling van de prijsindex; pensioenaanspraken van pensioengerechtigden zijn gewoonlijk waardevast.

b. de ontwikkeling van de loonindex; het eindloon is meestal de pensioenbasis en pensioenaanspraken zijn vaak welvaartsvast. 12

c. de reele rente; de reële rente is de disconteringsvoet waartegen de geindexeerde verplichtingen behoren te worden gedisconteerd. ${ }^{13}$

8. Zie bijvoorbeeld de teksten van de woordatachen die werden gehouden bij het VBA Seminar Matching op 14 rebruari 1989 in Amsiendam.

9. Zie Elton en Gruber (1988), Frijns en Goslings (1989) en Wolff (1989a, b)

10. Dit in tegenstelling tot de Moderne Portefeuille Theorle, in het kader watarvan de variantie wan het rendement op de activa-portef wille wordt gehanteerd ats risico-maatsial.

11. Zie Wolff (1989b).

12. Verondersteld wordt dat de financiering van de jauropbouw en de backservice in verband met carrière-ontwikkeling geschiedt ait pensioenprenies, terwijl de backservice op grond wan de algemene loonstiging dient te worden gefinancied wit de beleggingsopbrengsten.

13. Witgegan wordt van cen contante warde in economische zin. Actuarissen zouden de rekenrente als disconteringswoel gebruiken. 
In de Financierings-en Beleggingsliteratuur bestaan bepaalde technieken om de rentegevoligheid van activa en passiva op elkaar af te stemmen. 14 Dergelijke technieken zijn evenwel niet voorhanden om het (loon-of prijs-) inflatierisico te beheersen. In hoeverre inllatierisico kan worden gereduceerd is in principe en enpirische vrag. Het antwoord op deze vraag hangt af van de mate warin rendementen op individuele beleggingscategorieèn inflatiebestendig blijken. Een sterk risico-avers pensioenfonds zou een beleggingsportefeuille willen amhouden die net 20 inflatiegevoelig is als de pensioenverplichtingen. 15 Indien deze situatie bereikbaar is, spreken we van perfecte "matching" "Indien echter de diverse vermogenscategorieën onvoldoende weerstand. bieden tegen inflatie, wordt het moeilijk om perfecte "matching" te bereiken.

Met het oog op en afstemming van de beleggingen op de pensioenverplichtingen is het dus wan belang om nauwkeurig in kaart te brengen hoe rendementen op afzonderlijke beleggingscategorieen (aandelen, vastrentende waarden, onroerend goed) samenhangen met inflatie. Op basis van econometrisch onderzoek is het mogelijk om zogenaamde reactiecoëfficienten te bepalen, die aangewen in welke mate rendementen reageren op inflatie. 16 Recentelijk is een aan. wang gemaakt met dergelijk onderzoek voor de Nederlandse context. 17 De resultaten zijn evenwel weinig bemoedigend.

Beleggingen in aandelen blijken absoluut niet inflatiebestendig te zijn. Integendeel, op basis van alle beschikbare na-oorlogse gegevens moet worden geconcludeerd dat een loename van de prijsinflatie (in tegenstelling tot looninflatie) juist gepaard gaat met een forse afnome van het nominaal totaal rendement op aandelen, zodat het reële rendement op aandelen sterk onder druk komt te staan. Deze conclusie is geldig voor zowel verwachte als onverwachte inflatie. Beleggingen in obligaties bieden evenmin bescherming tegen onverwachte inflatie: ook hier betekent een onverwachte inflatietoename een lager nominaal en reeel obligatierendement. Alleen ten aanzien van verwachte inflatie bieden obligatierendementen een zekere bescherming. Empirische schattingen zijn evenwel verte van eenduidig. Sommige schattingen geven aan dat een extra procentpunt varwachte inflatie zich vertaalt in slechts 0,5 procentpunt additio-

4. Gedoen wordt op "immunisation", gebaseetd op het "duration" concept, en varianter dastop. Zie bifroorbeeld Fabozzi en Pollack (1987).

15. Eer pensiodn fonds da ín mindere mat risico-avers is, zou de perfect "gematche" portefenile als uigangspun nemen om darin een deel van het vemogen te beleggen. Da rest kan dan worden belegt in risicodragende beleggingsinstrumenten, bijvoorbeeld asndelen. De "gemachte" portefeuille spett dan als het wate de rol wan thet riscoloze beleggingsinstument in de Modene Porteleville Theorie, dat ook wordt gecombineerd met an risicodragende $\$$ tb portefulle, al hat gelang de mate van risico-aversie van de belegger.

16. Den god woobeeld vall dergelijk ondenzok (voor de Verenigde Staten) werd geleverd door Cama en Schuent (197\%).

17. Zic Frijns en Goslings (1989) en Wolf (1989a). 
neel nominaal rendement. Andere schattingen, daarentegen, wizen in de richting van een volle procentpunt extra nominaal rendement, zodat het reele rendement onaangetast bliff. 18 De bestendigheid van obligaties tegen tooninflatie is geringer en ligt dicht bij nul.

Vanuit de optiek van een pensioenfondsbestuur zijn deze onderzoeksresultaten uiterst teleurstellend. Zij geven namelijk aan dat "matching" in de praktijk waarschijnlijk niet mogelijk is. Zelfs wanneer obligaties volledig (prijs-jinflatiebestendig zouden $z i j n$, zou het op termijn geen uitkomst bieden om het totale beschikbare vermogen in vastrentende warden te beleggen, omdat het reele rendement te gering zou zijn om het hoofd te bieden aan de reële loonstijging. 19 De conclusie is dan ook onontkoombaar dat pensioenfondsen, bij een gegeven premie- en uitkeringsbeleid, er niet aan kunnen ontsnappen om gedurende inflatoire perioden hun vrije reserves te zien slinken. In perioden met relatief geringe inflatie, daarentegen, zullen de vrije reserves toenemen. Hopelijk kunnen deze fluctuaties in vrije reserves elkaar op langere termijn compense. ren. Het zal U inmiddels duidelik zijn dat er ten aanzien van dit vraagstuk nog veel onzekerheden bestaan. Hier ligt een uitdaging voor practisch ingestelde wetenschappers in de Financierings-en Beleggingsleer.

\section{Duurzame vermogensoverschottien?}

Op 10 juli 1987 hebben Minister Ruding en Staatssecretaris Koning van Financiën een Voorontwerp van Wet gepubliceerd met de titel "Wijziging van het fiscale regime voor onderhoudsvoorzieningen en spaarvormen alsmede voor verzekeraars en pensioenlichamen". Aan het voorontwerp werd de roepnaam "Brede Herwaardering" meegegeven. Er werd gekozen voor dle vorm van een voorontwerp om belanghebbenden en geünteresiseerden de gelegenheid te geven zich uit te spreken over de voorstellen, alvorens een definitief wetsvoorstel aan de Ministerraad voor te leggen.

Voor pensioenfondsen zou het voorontwerp hebben betekend dat zij vennootschapsbelastingplichtig worden:

"Pensioentichamen zijn (...) wrigesteld van de heffing van vennowschapsbelasting. Deze vrijstelling is in het leven geroepen ondat de wetgever erwan uitging dal de activiteiten van pensioenlichamen normatiter niet to het behalen van winst zullen leiden. Mocht w loch sprake zijn wan winst, dan zou

18. Voor onnotrend-goed heleggingen zijn onvoldoende data an werig on soortgelijke berekeningen te kunner maken. Vermoedelijk bieden rendementen op onoentand-goed beleggimgen een zekere bescherming tegen inflate, vooral ook gezien het feit dat wed hurgr zingendexerd. Dit geldt ook ten anzien wan de arbilrair gefixerde rekenrente van vide procent. 
die wan tijdelijke aard zijn en witeindelijk ten goede komen aan pensioengerechtigden, zo luidde de overweging die uit de wetsgeschiedenis kan worden afgeleid.

Aangezien gebleken is dat bij verschillende pensioenfondsen toch belangrijke reserves waar geen verplichtingen tegenover staan, zijn opgebouwd ${ }_{n}$ gaat deze overweging voor de huidige situatie niet meer op. Deze overschotten zijn fiscaal eigenlijk als winst aan te merken. Voorgesteld [wordt] om (...) pensioenlichamen in de (vennootschaps)belastingheffing te betrekken."

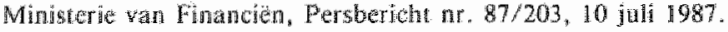

Over het voorontwerp is overleg gepleegd met verzekeraars en met vertegenwoordigers van pensioenfondsen. Na enige tijd heeft de Vereniging van Bedrijfspensioenfondsen het overleg afgebroken, omdat de standpunten te ver uiteen lagen. Een deel van de argumentatie om pensioenfondsen vennootschapsbelastingplicht op te leggen berustte op de veronderstelling dat pensioenfondsen en levensverzekeringsmaatschappijen directe concurrenten zouden zijn en derhalve fiscaal gelijk behandeld dienen te worden. Deze veronderstelling werd met kracht tegengesproken door levensverzekeraars zowel als pensioenfondsen en is inmiddels door de bewindslieden verlaten.

De Minister en Staatssecretaris van Financiën hebben vervolgens het voorontwerp "Brede Herwaardering" opgesplitst in twee aparte wetsvoorstellen, warvan één geheel gewijd is aan de behandeling van eventuele vermogensoverschotten van pensioenfondsen. Dit wetsvoorstel is getiteld "Regels betreffende een heffing over vermogensoverschotten van pensioenfondsen (Wet op de heffing over vermogensoverschotten van pensioenfondsen)." In de inleiding van de bijbehorende Memorie van Toelichting wordt het volgende gesteld:

"In de jaren tachtig is de verhouding tussen beleggingsrendementen enerzijds en de loonontwikkeling anderzijds sterk verbeterd. Het gevolg hiervan is dat bij pensioenfondsen de feitelije dekkingsgraad van de opgebouwde pensioenrechten witstijgt boven die wetke noodzakelijk is om aan de verplichingen le voldoen. Met andere woorden, er is bij pensioenfondsen een ontwikkeling gaande waarbij vermogensvorming optreedt waar geen (direct aanwijsbare) pensioenverplichtingen tegenover staan."

"Het onderhavige wetswoorstel beoogt het vormen van deze vermogensoverschotien door pensioenfordsen tegen te gaan door invoering van een eigensoortige heffing over vermogensoverschotten met een duurzarm karakler."

Memorie van Toelichting, p.2. 
De plannen van de inmiddels demissionaire bewindslieden houden in dat op 1 januari van elk jaar op basis van een aantal waarderingsvoorschriften het vermogensoverschot of -tekort van een pensioenfonds wordt gemeten en geregistreerd. Wanneer alle bezittingen en schulden zijn berekend en er een deel van het vermogen overblijft waar geen schulden tegenover staan, dan is er, na inachtneming van een zekere marge, sprake van een vermogensoverschot. Wordt een dergelijk vermogensoverschot geconstateerd, dan gaat een termijn van vijf jaar in, waarbinnen dat vermogensoverschot kan worden weggewerkt door premieverlaging, premieterugbetaling of verbetering van rechten. Indien er na afloop van de termijn van vijf jaar nog steeds sprake is van een overschot, dan wordt in het zesde jaar veertig procent belasting geheven over de laagste stand van het vermogensoverschot op één van de zes peildata. Heffing kan ook worden voorkomen door in het vijfde jaar de pensioenpremie op nihil te stellen. De bewindslieden achten het waarschijnlijk dat pensioenfondsen maatregelen zullen treffen om heffing te voorkomen. Wanneer pensioenpremies worden verlaagd of rechten worden verbeterd, zullen evenwel direct budgettaire baten ontstaan in de vorm van extra opbrengsten van de inkomstenbelasting, de premies volksverzekeringen en de vennootschapsbelasting. Het niet, of in mindere mate, afdragen van pensioenpremies leidt immers tot hogere belastbare inkomens bij individuen en hogere winsten bij bedrijven.

Het is interessant om ons af te vragen hoe het onderhavige wetswoorstel zich verhoudt tot de onderzoeksresultaten met betrekking tot afstemming van beleggingen van pensioenfondsen op de pensioenverplichtingen. Sinds 1983 is de inflatie in Nederland zeer laag geweest. Op basis van de eerder genoemde schattingen ten aanzien van de inflatiebestendigheid van beleggingsrendementen, is het zeer voorspelbaar dat een aantal pensioenfondsen momenteel beschikt over aanzienlijke vrije reserves. Dit effect wordt versterkt door het feit dat het hogere rendement op oudere obligaties en onderhandse leningen nog enige jaren naijlt. Wanneer de inflatie weer zou oplopen, en er zijn reeds tekenen waar te nemen die hierop wijzen, dan zullen diezelfde vrije reserves spoedig slinken. Bij bestendige inflatie zal wederom een moment aanbreken waarop er bij pensioenfondsen sprake zal zijn van onderdekking. Obligaties en onderhandse leningen die in het recente verleden zijn aangekocht respectievelijk verstrekt zullen in een dergelijke situatie fungeren als accelerator van de problemen, vanwege het relatief lage rendement dat dan uit her verleden wordt meegedragen. De indruk valt derhalve niet te vermijden dat de bewindslieden zich laten leiden door een toevallige piek in de vrije reserves van pensioenfondsen, die weer snell kan verdwijnen.

Overigens is het begrip overschot zeer relatief. Het Centraal Planbureau heeft in 1986 een studie gepubliceerd waarin de actuariële saldi van de bedrijfs" en ondernemingspensioenfondsen werden becijferd bij verschillende rekenrentes. Bij de "officiële" rekenrente van $4 \%$ werd een totaal actuaricel saldo van $f 85$ mrd berekend. Bij een rekenrente van $2 \%$ sloeg dit om in een tekort 
van $f 44$ mrd en bij een realistische rekenrente van 1 to zelfs in een tekort van $f 152$ mrd 20 Op basis wan deze cijfers is de Sociaal Economische Raad tot de volgende uitspraak gekomen:

"Het zou onjuist ziln indien op basis wan de huidige overrente de conclusie zou worden getrokken dat er bij de fondsen sprake is wan overschatten". Socidal Economische Rad, Advits Pensioenbegparingen, p. 37.

Sommige pensioenfondsen zijn overigens zelf van mening dat zij relatief ruim in hun jas zitten en zijn dientengevolge overgegaan tot (soms aanzienlijke) premieverlaging. De Minister en Staatssecretaris wan Financièn vertonen even wel een witzonderlijk gedetailleerd inzicht in de "matching"-problematiek wanneer $z \mathrm{ij}$ in de Memorie van Toelichting op de woorgestelde Wet op de Heffing over Vermogensoverschotten van Pensioenfondsen stellen:

"Een (...) mogelijk geworden werlaging van pensioenpremies heeft niet in voldoende mate plaatsgevonden"

Memorie wan Toelichting, p. 2.

Te voorzien valt overigens dat de woorgestelde wet ingrijpende gevolgen zal hebben voor de premievaststelling. Wanneer pensioenfondsen niet meer in voldoende mate reserves kunnen opbouwen om perioden van tegenspoed te kunnen doorstaan, zullen pensioenpremies die door werkgevers en werknemers worden betaald vrij hevig gaan fluctueren met de dekkingsgraad van de fondsen. Daar komt bij dat de perioden met hoge premies precies dié perioden zullen zijn waarin de reële rendementen op niet-contractuele besparingen laag uitvallen en de aandeelkoersen van bedrijven toch al onder druk staan.

De Raad van State heeft op 17 mei 1989 een advies uitgebracht, waarin werd geconcludeerd dat er geen overtuigende gronden zijn aan te voeren die tot de voorgestelde regelgeving moeten leiden. De bewindslieden werden nadrukkelijk uitgenodigd on de eventuele anwezigheid van vermogensoverschotten en het duurzame karakter darvan cijfermatig aan te tonen. Zij zijn op deze uitnodiging niet ingegaan. In het genoemde advies toont de Raad van State een helder inzicht in de materie:

"Mocht inderdaad thans sprake zijn van een overbodige ophoping van activa bij een aantal fondsen, dan is het hog de vraag of dit niet het gevolg is van een samenloop van omstandigheden. Als een zodanige samenloop wan omstandigheden kumnen immers worden gezien de achter ons liggende periode van relatieve matiging van de lonen, de lage inflatie - zelfs enige voorbigaande prijsdaling - samen met hage nominale rendementen op

20. Zie Bolbuis en Vossers (1986). Het genuiddelde reële rendement op whingaties in de natoorlogse periode bedragt minder dan êten procent. 
siaatsleningen uit voorbije jaren. Het is deugdelijk pensioenbeleid er rekening mee te houden dat eer dergelike samemloop vam omstandigheden welvicht geheel wan voorbijgande aard is, maar zich ook in tegengestelde zin kan voordoen".

Advies van de Rara wan State, p. 34.

De Raad komt vervolgens tot een ongebruikelijk krachtige uitspraak:

"De conclusie kan voor de Raad geen andere zijn, dan dat dit voorstel van wet niet moet worden ingediend".

Advies wan de Raad val Stare, p. 12.

en eindigt het advies aan de Koningin met de volgende woorden:

"De Raad van State heef blikens het voorstaande bewwar tegen zowel de vorm als de inhoud van het voorstel van wet en geefi $U$ in overweging om dit niet te zenden aan de Tweede Kamer der Staten-Generaal".

Advies van de $\mathbb{R}$ aad van State, p. 22.

De beide demissionaire bewindslieden, daartoe gemachtigd door de Ministerraad, verzochten echter in hun nadere toelichting om toezending van een slechts marginaal gewijzigde versie van het wetsvoorstel aan de Tweede Kamer, hetgeen is geschied op 27 juni 1989.

De vraag blijft waarom de Minister en de Staatssecretaris van Financiën het wetsvoorstel tegen de stroom in blijven verdedigen. Er zijn tekenen die erop wijzen dat korte-termijn budgettaire motieven de boventoon voeren. Aan het wetsvoorstel zitten immers aantrekkelijke kanten, gezien vanuit 's Rijks schatkist. Pensioenfondsen kunnen de vermeende overschotten laten voortbestaan en veertig procent ervan afdragen aan de fiscus, of ze kunnen de vrije reserves afbouwen, in welk geval indirecte budgettaire baten ontstaan in de sfeer van de inkomstenbelasting, de premies volksverzekeringen en de vennootschapsbelasting. Elk van beide scenario's resulteert in een miljardenvoordeel voor de staatskas. In dit kader is het opvallend dat in Memorie van Toelichting op het wetsvoorstel de extra opbrengsten zijn becijferd tot in het jaar 2005, terwijl, zoals eerder opgemerkt, de aanwezigheid van permanente vermogensoverschotten niet eens met gegevens werd onderbouwd.

Naast de directe of indirecte fiscale consequenties zou een additioned financieel voordeel voor het Rijk ontstaan, wanneer het wetswoorstel tol wet verheven zou worden. De overheid is immers de grootste werkgever in Nederland. Premiereducties of -terugbetalingen die het ABP (het pensioenfonds voor ambtenaren, onderwijzend personeel en werknemers bij semi-overheidsinstellingen) of het PGGM (het pensioenfonds voor de gezondheids- en welzijnszorg) zouden toepassen, zouden reeds op korte termijn baten opleveren voor de schatkist. Deze baten zouden niel leiden tot ongunstiger cijfers ten aanzien van 
de belasting en premiedruk. Dit laatste is voor regeerders niet onaantrekkelijk, getuige ook de bereidheid om de vrije reserves van het PGGM te doen aanspreken teneinde in het recente loonconflict in de gezondheidszorg tot een oplossing te geraken.

Overigens is de overheid in stat om de afstemming van de beleggingen van pensioenfondsen op de verplichtingen in belangrijke mate te vergemakkelijken. Wanneer de Minister van Financien erin zou toestemmen om tegen inflathe gendexerde obligaties en onderhandse leningen uit te geven, zouden pensloentondsen deze in hum portefeuilles opnemen vanwege het inflatiebestendige karakter van dergelijke vermogenstitels. De hoofdsom en wellicht de couponbetalingen zouden immers worden gecorrigeerd voor het verloop van de prijsindex. Via geindexeerde staatsleningen zou "matching" van beleggingen eri verplichtingen aammerkelijk minder problemen geven en de overheid zou, desgewenst, met meer precisie en geloofwardigheid kunnen bepalen of een pensioenfonds wel of niet een vermogensoverschot heeft. Tot op de dag van vandaag zijn verschillende Ministers van Financiën niet bereid geweest om geindexeerde staatsleningen uit te geven, ondanks de evidente voordelen die daaraan zijn verbonden voor de schatkist en voor de beteugeling van de inflatie op langere termijn. 21 Wellicht is de tijd rijp om ook de discussie omtrent dit onderwerp nieuw leven in te blazen.

\section{Beleggingsvoorschriften (of beleggingsdwang?)}

Aan het begin van mijn rede heb ik de wisselwerking tussen het beheer van pensioengelden, aan de ene kant, en de institutionele en maatschappelijke ongeving, aan de andere kant, aan de orde gesteld. In het betoog tot nu toe heeft de nadruk gelegen op de omvang van de beleggingen van pensioenfondsen. Daarnaast is evenwel sprake van een wisselwerking waar het de aard van de beleggingen betreft, zij het dat er af en toe meer sprake lijkt van éenrichtingsverkeet dan van een wederzijdse beinvloeding.

Tijdens de behandeling van een wetsontwerp tot wijziging van de Pensioen- en Sparfondsenwet in de Tweede Kamer in oktober 1980, werd de volgende motie met een ruime kamermeerderheid aanvaard:

21. Zie 0.ä. Bomhofr $\left(1983 \mathrm{a}_{\mathrm{b}} \mathrm{b}\right)$ asmede Jonkhart en Walschots (1988). Jonkhart, en Walschots katien het standpunt wan de Staat kenachtig samen: "de. Stoal wenst geen gebrwik te maken ran geindexeerde leningen". Bomhoff gaat in detail in op de voordelen van geindexeerde staatsleningen in de Nederlandse context. 
"De Kamer,

gehoord de beraadslaging;

overwegende, dat in verband met de aan hen toevertrouwde belangen institutionele beleggers in toenemende mate beleggingen verrichten in het butenland;

overwegende, dat deze beleggingen schadelijke neveneffecten kunnen opleveren voor de Nederlandse economie;

van mening, dat er sprake is wan een achrerblijven van investeringen in bijzonder gewenste maatschappelijke projecten, zoals wonimgbouw, het milieu en de energiebesparing;

van oordeel dat maast andere middelen ook beleggingswoorschriften waarbij een redelijk rendement wordt gegarandeerd, een bijdrage zouden kunnen leveren tot de oplossing van deze situatie;

werzoekt de Regering, een onderzoek in te stellen naar de mogelijkheden wan beleggingswoorschriften ter bevordering wan investeringen in projekten yan grote maatschappelijk warde en daarover de Kamer (...) in te lichten,

en gaat over tot de orde van de dag"”.

Handelingen, Tweede Kamer, 21 oktober 1980.

De regering heeft destijds uitvoering van de motie toegezegd onder voorwaarde dat in de eerste plaats de wenselijkheid en vervolgens eventueel de mogelijkheden van de in de motie bedoelde beleggingsvoorschriften zouden worden onderzocht. In juni 1980 werd door de toenmalige Minister van der Stee van Financiën een Nota Beleggingsvoorschrilten aan de Tweede Kamer angeboden. In de nota werd geconcludeerd dat de invoering van beleggingsvoorschriften niet wenselijk werd geacht, onder andere omdat een dergelijke vorm van ingrijpen in het marktmechanisme de prijsvorming sterk zou verminken, evenals de signaalwerking die bij niet gereguleerde vraag- en aanbodverhoudingen van relatieve prijzen uitgaat. Voorts probeerde de Minister aannemelijk te maken dat beleggingsvoorschriften niet tot het gewenste doel zouden leiden, en wellicht zelfs het tegendeel zouden kunnen bewerkstelligen. 22 Het standpunt van de Minister werd in onathankelijke adviezen onderschreven door De Nederlandsche Bank, de Centrale Beleggingsraad, de Verzekeringskamer en de Adviescommissie voor Pensioenen.

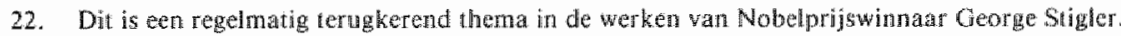


Een van de steunpilaren van de moderne beleggingsleer is de theorie van Harry Markowitz ${ }^{23}$ die aangeeft, onder een aantal veronderstellingen, hoe beleggingsportefeuilles optimaal kunnen worden opgebouwd. "'Optimaal" betekent hier dat een portefeuille wordt geconstrueerd die, gegeven het spectrum van beleggingsmogelijkheden, en gegeven de risicohouding van de belegger in $k$ westie, leidt tot een zo hoog mogelijk nutsniveau. Het nut hangt niet alleen af van het rendement dat men met de portefeuille verwacht te behalen, maar ook van het risico dat de portefeuille in zich bergt, waarbij verwacht rendement positief wordt gewaardeerd en risico negatief. Deze theorie wordt vandaag de dag alom gebruikt in de beleggingspraktijk.

Het is verhelderend om beleggingsvoorschriften te interpreteren in het licht van de theorie van Markowizz. Zonder beleggingsvoorschriften kiest een belegger de portefeuille die voor hem of haar optimaal is. Wanneer nu beleggingsvoorschriften worden opgelegd, pleegt de relevante set van beleggingsmogelijkheden te worden verkleind. ${ }^{24}$ Immers, een extra restrictie wordt opgelegd. Met behulp van een elementaire optimaliseringsmethode kan worden aangetoond dat de beleggingsportefeuille die in de nieuwe situatie wordt gekozen inferieur zal zijn aan de oorspronkelijke optimale portefeuille. Dit wil zeggen dat de nieuwe portefeuille een lager verwacht rendement zal hebben, of een hoger risi$\mathrm{co}$, of beide. De restrictie brengt een aantasting van het welvaartsniveau van de belegger met zich mee.

Wanneer we dit gegeven gebruiken om de rol van beleggingsvoorschriften voor pensioenfondsen te bestuderen, ontstaat het volgende beeld. De overheid zou omwille van het realiseren van nader te definiëren bijzondere doelstellingen beleggingsvoorschriften kunnen opleggen aan pensioenfondsen. Voor de pensioengerechtigden houdt dit in dat de beleggingsportefeuille waaruit hun pensioenen dienen te worden gefinancierd een profielwijziging ondergaat. Een lager verwacht rendement, een hoger risico of een combinatie van deze factoren leidt tot een waardedaling van de contractuele besparingen van de inclividuele deelnemer in een pensioenfonds; premieverhogingen komen in zicht. De bijzondere doelstellingen van de overheid worden kennelijk geheel of gedeeltelijk gefinancierd uit een soort belasting die wordt opgelegd aan burgers die premies afdragen in het kader van (verplichte) pensioenregelingen. Zolang het belang van de doelstellingen dit rechtvardigt en de verdeling van lasten weloverwogen plaatsvindt, is hier natuurlijk niets op tegen. Democratisch genomen overheidsbeslissingen dienen te worden gerespecteerd en het ligt niet in mijn bedoe-

23. Zie Markowila (1970) voor een gedetailleerde beschrifving van de veronderstellingen die in deze paragraal impliciet worden gehanteerd.

24. Behoudlens vitzonderingsgevallen watrin de additionele restrictie niet bindend blijkt. In deze situaties zal de portefeuillemkeuze met extra restrictie niet verschillen van de portefenille-keuze zonder die restrictie. Zie Markowitz (1970). 
ling om in deze rede politiek te bedrijven. Wèl wil ik opmerken dat de financiêle gevolgen moeilijk zijn te traceren, omdat de effecten indirect optreden. Daar komt bij dat de financiële kosten van dergelijke maatregelen niet aan het licht komen in cijfers omtrent de belasting-en premiedruk, hetgeen weleens verleidelijk zou kunnen blijken. In dit kader lijkt het juister om de bijzondere doelstellingen te verwezenlijken via het budgetmechanisme, opdat zij in openheid kunnen worden afgewogen tegen andere overheidsuitgaven en tegen de kosten die uit de doelstellingen voortvloeien in de vorm van verhoging van belastingen of heffingen. Tevens wordt op deze manier hopelijk voorkomen dat informatie omtrent de financiële bijdragen van bepaalde groepen burgers verloren gaat of onvoldoende gewicht krijgt.

Niettegenstaande het toenmalige regeringsstandpunt inzake beleggingsvoorschriften en niettegenstaande de verworvenheden van Harry Markowitz' theorie, blijft de roep om beleggingsvoorschriften bestaan. In een discussienota van de Federatie Nederlandse Vakbeweging wordt gesteld:

"Het beleggingsbeleid dat de FNV voorstaat is werstrekkender wan aard en is gericht op beinvloeding van beleggingen van institutionele beleggers vanuit sociaal-economische doelstellingen. (...) Dit betekent dat een beleggingsbeleid onderdeel vormt van het totale social-economische beleid en als zodanig ook beoordeeld dient te worden".

"Het beleggingsbeleid kan (...) vorm krijgen (...) via door de overheid te bevorderen afspraken en zonodig te stellen regels ..."

"In dit verband zal een deel van de middelen van de institutionele beleggers voor een redelijke prijs beschikbaar moeten worden gesteld voor de sociale woningbouw en de woningvernieuwing".

"De vraag is verder of alle institutionele beleggers in éen gezamenlijk fonds onder de afspraken of zonodig voorschriften wallende bedragen dienen te storten en dat vervolgens vanuit dit fonds deze beleggingen plaatsvinden"."

Federatie Nedlerlandse Vakbeweging (1983), pp.9-13.

Bij de behandeling van de Miljoenennota 1987 en bij het debat over de wijziging van de Algemene Burgerlijke Pensioenwet in juni 1987 hebben ook leden van de Tweede kamer aangedrongen op beleggingswoorschriften en aanverwante maatregelen. 


\section{Deleggen in het buitenland}

Het Algemeen Burgerlijk Pensioenfonds is onderworpen aan een aantal concrete beleggingswoorschiften. Zo mag het ABP niet meer dam vijf procent van de beleggingsportefeuille in het buitenland beleggen, en zijn beleggingen in aandelem en onroerend goed te zamen gebonden aan cen maximum van twintig procent. Daarnatst is het $\mathrm{ABP}$, tot een zeker maximum, verplicht om deel te nemen in geldleningen ten laste van de Staat, mag het fonds geen groter belang hebben in een aan de beurs genoteerde onderneming dan vijf procent van het geplaatste kapitaal (vijftien procent voor beleggingsfondsen) en zijn korte uitzettingen gebonden aan een bovengrens. Het ABP is aan strengere regels onderworpen dan andere, niet-publiekrechtelijke pensioenfondsen.

Beleggen in het buitenland mag het ABP pas sinds begin 1988 , zij het op voornoemde beperkte schaal. Bij de behandeling van de wijziging van de Algemene Burgerlijke Pensioenwet en de Beleggingswet in de Tweede Kamer in juni 1987 bleek dat lang niet alle Kamerleden beleggen in het buitenland een vanzelfsprekende zaak vonden. Het kamerlid Wöltgens verklaarde:

"Xk ach het op principiele gronden (...) verdedigbaar dat het ABP en het PGGM als overheidspensioenfondsen nooit in sraat worden gesteld te beleggen in het buitenland maar zeker in de huidige situatie, warin wij zoeken naar financieringsmogelikheden buiten de begroting om woor stimulering wan de Nederlandse economische groet, meen ik dat niet de mogelijkheid moet worden geopend om het allergrootste pensioenfonds de gelegenheid te geven in het buirenland te beleggen".

Handelingen, Tweede kamer, juni 1987.

Regelgeving die inhoudt dat het ABP wordt beperkt in zijn mogelijkheden om in het buitenland te beleggen, wordt door een aantal parlementariërs wenselijk geacht om meer financiële middelen binnen Nederland te houden opdat de economische groei daardoot wellicht wordt aangewakkerd. Wanneer het ABP evenwel met gelden die nu in buitenlandse aandelen worden belegd, Nederlandse aandelen zou gaan aankopen, zou hiervan naar alle waarschijnlijkheid een koersverhogende werking uitgaan. De huidige beleggers in deze aandelen zouden hiermee gebaat zijm, maar er zouden geen extra middelen toevloeien aan het Nederlandse bedrijfsleven. 25 Wel zouden bedrijven in stat zijn om tegen gunstiger voorwaarden risicodragend vermogen aan te trekken.

De Europese Conmissie benadert de problematiek vanuit een andere optiek. In een mededeling inzake de totstandkoming van een Europese financiële rümte, wordt door de Commissie het volgende voonnemen verwoord:

25. Behalwe voorzover ondermemingen andelen aanhouden in andere, aan de beurs genoteerde ondernemingen. 
"Een aantal Lid-Statern kennen pensioenfondsen niet het rech toe in bultenlandse effecten te beleggen of beperken de mogelikheden daartoe; aldus belemmeren zij het wrije kapitaalverkeer.

De Commissie is zich bewust van het feit dat een bepalde worm van bedrijfseconomisch toezicht in het geval van pensioenfondsen gerechrvarm digd kan zijn. De beperkingen zijn echrer naar haar mening buitensporig. Zij is voornemens besprekingen met de betrokken Lid-Staten te openen ten einde te komen tot een geleidelijke opheffing van deze beperkingen".

Mededeling wa de Commissie, Totstandkoming wan cen Europese funancièle ruiznte, Document COM(87) 550 def, 1987.

Voor iemand die deze problematiek benadert vanuit de beleggingstheorie, is het moeilijk te begrijpen dat een dergelijke discussie noodzakelijk is. Vrijwell alle studies die de internationale beleggingsliteratuur heeft voortgebracht wijzen er immers op dat internationaal beleggen een gezonde zaak is die het gemiddeld rendement of het risicoprofiel van een beleggingsportefeuille, of zelfs beide, bellangrijk kan verbeteren. ${ }^{26}$ In deze tak van de literatuur wordt aangegeven dat beleggingen in het buitenland diversificatievoordelen met zich meebrengen. Buitenlandse aandeelkoersen, en koersen van andere buitenlandse vermogenstitels, fluctueren lang niet. altijd in tandem met hun Nederlandse tegenhangers. Internationale spreiding leidt derhalve tot een verbetering van de prestaties van een portefeuille: een hoger verwacht rendement bij een gelijk risico, een lager risico bij een gelijk verwacht portefeuillerendement, of een combinatie van deze twee mogelijkheden. Cijfers laten zien dat deze voordelen van internationale spreiding over een wat langere periode niet worden geneutraliseerd door wisselkoersbewegingen 27 , zelfs niet wanneer wisselkoersbewegingen volledig onvoorspelbaar zijn. 28

De restrictie op buitenlandse beleggingen door het $\mathrm{ABP}$ heeft dus tot resultaat. dat de beleggingsportefeuille van het ABP minder goede prestaties levert dan zonder die restrictie mogelijk zou zijn. Hiervan kan alleen maar een premieverhogende werking uitgaan. Ambtenaren zullen hieraan in belangrijke mate moeten bijdragen.

26. Zie Adler en Dumas (1983). Black (1989), Cholerton, Pieraerts en Solnik (1986), Ibbotson, Siegel en Love (1985), Lee (1987), Kaplanis (1988), Logwe (1982), Madura en Reeff (1985), Shaked (1985), Solnik (1974), Solnik (1988), Solnik en Noetzlin (1982). In deze Jiterattun wordt ervan uigegaan dat belegd wordt in kapitaxamarktan van landen met ontwikkelde economizën, die niei onderhewig zijn aan pollitiek risico.

27. Zie bijwoorbeeld Solnik (1989).

28. De resultaten wan een aantal onderzoeken geven aan dat wisselkoensmulaties indwdalad wrijwel onvootspelbaar zijn. Zie Meese en Rogoff (1983) en Wolff (1987. 1988a, 1988b). 


\section{Resluin}

Financherings-en beleggingsaspecten van pensioenverzekeringen staan volop in de (politieke) belangstelling. In augustus wan dit jaar nog heeft de demissionaire Minister van Financién, Ruding, samen met zijn collega van Binnenlandse Zaken, Van Dik, een nieuw wetsvoorstel over een llexibel premiesysteem voor het Algemeen Burgerlijk Pensioenfonds toegestuurd aan de Raad van State 29 In het premiesysteem dat in het wetsvoorstel wordt uitgewerkt, wordt rekening gehouden met de verwachte loonontwikkeling in de overheidssector voor de eerstkomende wier jaar en met de verwachte beleggingsresultaten bij het ABP in die periode. Het is de bedoeling dat de overheid rumschoots van tevoren kan zien aankomen hoe hoog de premies in de komende jaren zullen zijn, opdat deze gegevens kunnen worden gebruikt bij het opstellen van de Rijksbegroting. Een dergelijk systeem heeft natuurlijk een directe relatie met het "matching" "wraagstuk en de vraag is wederom war in de toekomst de nadruk zal liggen: bij de belangen van pensioengerechtigden of bij de financieringsbehoefte van de overheid?

In de matschappelijke en politieke discussie omtrent pensioenen die momenteel wordt gevoerd, vallen tallijke ontwikkelingen te ont waren die de financiäle soliditeit van ons pensioensysteem ondermijnen. Ik spreek de hoop uit dat de verworvenheden van de Financierings- en Beleggingsleer in voldoende mate zullen prevaleren om te voorkomen dat het element "zeker" in het woord "pensioenverzekering", van vraagtekens dient te worden woorzien.

29. Aan de Verzekeringskamer en her. Central Georganiseerd Overleg in Ambienarenzaken is ook om advies gevraagd. De Ministerraad zal na ontvangst van de drie adviezen het voorsiel opnieuw agenderen. 


\section{Dankwoord}

Bij de voorbereiding van deze rede heb ik gebruik gemaakt van de nuttige adviezen van drs. P.M.A. Eichholtz, dr. J.M.G. Frijns, prof. dr. J.H.W. Goslings, prof. dr. A.C.C. Herst, drs. W.F.A.M. Naber en drs. V.L.M.C. Petri. Gaarne wil ik hen op deze plaats bedanken, met de aantekening dat ik alléén de verantwoordelijkheid draag voor de inhoud van het eindproduct. Voorts wil ik een woord van dank richten tot de heer H.J. Rademaker voor zijn voortreffelijke ondersteuning bij het verzamelen van de documentatie, alsmede aan mevrouw C.G.M.P. van den Boorn en mevrouw C.J.L.M. Schreuder voor hun gewaardeerde hulp bij de tekstverwerking. 
Aalsi, P. C. van, "De Beleggingsportef wulles van Pensioenfondsen", Econowisch Siavisioche Berictiven, 23 jull 1986.

Actuaitel Genootschajs; Interimrapport Werkgroep Matching, 1980.

Adler, M. w B. Dumas, "International Porfolio Choice and Corporation Finance: A Synthesis". Journal of Finance, $38, n, 3,1983,50.925-984$

Algemeen Burgerlijk Pentsionlonds, Nota Vermogensstructuur en Matching, 1988.

Agemeen Burgerlijk Pensioenfonds, Jourverslag, diverse jaren, 's-Gravenhage/Heerlen.

Algemeen Burgerlijk Pensioenfonds, Balanscommissie, Achthende Welenschappelijke Balans van Wet Algemeen Burgerlijk Pensioenfonds, "s-Gravenhage, Staatsuitgeverij, 1986.

Algemene Rekenkamer, Verslag wan de Afgentene Rekenkumer, diverse jaren, Statsuitgevenii, 'sGravenhage.

Backhaus, J.G., De Financiering van de Wefvarisstaut, Oratie, Rijksuniversiteir Limburg, Maasiricht, 1989.

Berg, P.S. van den en I.H. Tamerus, "Wennootschapsbelasting voor Pensioenfondsen: Optisch Bedrog" "Ecomomisch Statistische Berichen, 28 oktober 1987.

Besseling, P.J. en H.M.J. Sctheepers, Een Vergelijkend Onderzoek van 45 Pensioenregelingen in Nederland, Statsuitgeverij, "s-Graverhage, 1981.

Bierwag, G.O., G.G. Kaufman en A. Toevs, "Duration: Its Development and Use in Bond Portow lio Managemen!", Financial Analysts' Journal, juli/augustus 1983, pp. 15-35.

Black, F, Unversal Hedging, Goldman Sachs, New York, 1989.

Bollhuis, E.A. en W.J. Vossers, Pensioenfondsen in Mederland, een Modelanalyse, Centraal Planbureau, Occasional paper nt. 38, Den Haag, 1986.

Bomhor, E.J., "Geindexeerde Financiële Titels en Pensioenen", in." A.C.C. Herst e.a. Financie ring on Beforgings. Stand wan Zaken Anno 1983, Erasmus Universiteil Rotterdam, 1983a.

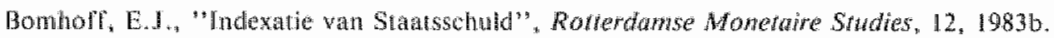

Bomholl, E.J., "Finamcien"ingstekon en Pensioentegelingen" "Economisch Statisfische Berichten, 25 mant 1987.

Bosch, F. A.J. van den, P.J.C. van Eekelen en C. Petersen, "De toekomst van de AOW: Verdubbeling van Premies of Halvering van de Uitkeringen?" "Economisch Statistische Berichten, 16 novernber 1983.

Centrat Bureau voor de Statistiek, Maandstatistiek Financiemezen, diverse jaargangen.

Cholerton, K., P. Pieraerts en B. Solnik, "Why Inwest in Foreign Currency Bonds?", Journal of Portfotio Monagement, Summer 1986, pp. 4-8. 


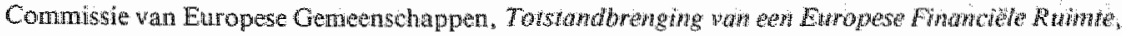
Document COM(87) 550 def, Bnussel, 1987.

Dams, J.A.M., "Pensioenfondsen en Heffing Vennootschapsbelasting, Thidschrof woor Pensioenwaagstukken, okiober 1987, pp. 85-87.

Davis, E.P., "Financial Marker Activity of Life Mnsarance Companies and Pension Funds, Bank for International Settlements, BIS Economic Papers nt. 21. 1988.

De Nederlandsche Bank, Jatarverslag, diverse jaren.

De Nederlandsche Bank, Kwartadbericht, diverse jaargangen.

Eichnoltz, P.M.A. en C.C.P. Wollf, "Asset-Allocatie Sof ware: Inventarisatie en Beoordeling", te verschinnen in Bedrijskunde, 1990.

Eje, J.H. wan e.a. (red.), Economie van her Verzekeringsbedrij, Kluwer, Deventer, 1987.

Elton, E.J. en M.J. Gruber, "Optimal Investment Strategies with Irvestor Liabilities", Working Poper, Graduate School of Business Administration, New York University. 1988.

Fabozzi, F.J. en I.M. Pollack, The Handbook of Fixed Income Securities, 2e editie, Dow JonesIrwin, Homewood, 1987.

Fama, E.F. en G.W. Schwert, "Asser Returns and Inflation", Journat of Financial Economics 5, 1977 , pp. 115-146.

Fase, M.M.G., "Bond Yields and Expected Inflation: A Quantitative Analysis of the Dutch Experience, Reprint no. 2, De Nederlandsche Bank, Ansterdam, 1977.

Federatie Nederlandse Vakbeweging, Dischssienota Beleggingen van Pensioenrondsen en Andere Instifutionele Beleggers, 1983.

Fischer, 1., The Theory of Interest, Porcupine Press, Philadelphia, 1977 (oorspronkelijke uitgave 1930 .

Frijns, J.M.O. en J.H.W. Goslings, "Matching voor het Pensioenbedrijf in Nominale en Reelle Termen", Economisch Statistische Berichten, 6 september 1989.

Goslings, "Matching bij Pensinen-en Levensverzekeringen", in: J.H. vin Eije e.a. (red.), Erono. mie wan het Vercekeringsbedrifs, $\mathbb{R}^{\prime \prime l}$ luwer, Deventer, 1987, pp. 81-90.

Goudswaard, K.P. en H.M. vari de Kar, "Institutionele Beleggers en Owerheidsschuld", Economisch Statistische Berichen, 26 maart/2 april 1986.

Hart, J..l. "t en E.E. van Laer, "Totale Redementsindices woor de Nederlandse Kapitaulmarkien, Roulterdanse Moneraire Sindies, nt. 17, 1984.

Huijger A.P. en P.D. van Loo, "Vergrijzing, Pensioenen en Contractuele Besparingen" , Monetaire Monografië̈n, nr. 5, De Nederlansche Bank. A.risterdam, 1986.

Ibbotson, R.G., L.B. Siegel en K.S. Love, "World Wealth: Market Values and Returns", Journal of Porifolio Managemen, Fall 1985, pp. 4-23. 
Janten, T", "De Balang war het ABP". Ecowomisch statistische Bericher, 25 april 1984.

Janssens, R.P.W. "Matching" van de Beleggingen en Verplichtingen wan tem Pensioentonds binWen het Kader van de Modeme Portefeulle Theorie ${ }^{3}$, Doctoralscriphe, Faculieit der Economische Werischappen, Rijksuniversiteil Limbarg, 1988.

Jonkhart, M.J.L. en B.C.J. Walschots, "Fet Financieringsbeleid wan de Staat der Nederlanden" " Econownisch Staristische Berichten, 6 januari 1988.

Kaplanis, "Stability and Forecasing of the Comovement Measures of International Stock Market Returns", Journat of Internationat Montey and Finance, 7, no. 1, pp. 63-75.

Kuné, J.B., "Het Vernogen der Pensioenfondsen, te Groot?" "Tijdschrift voor Pensioemuratagsiuk ken, januatri 1988 , pp. 5-9.

Kuné, J.B., Pensioen en Economie; Enige Financieet-economische Aspecten van Pensioenvoorzieningen, Academisch Proe/schirft, Amsterdam, 1987.

Langetieg, T.C., L.N. Nader, M.L. Leibowizen A. Weinberger, Measuring Effective Durotion of Pernion Liabilities, Salomon Brothers Ine., Bond Portfolio Analysis Group. New York, 1986.

Lee, A.fF." "International Asset and Currency Allocation", Journall of Portfolio Mandogement, Fall $1987, \mathrm{pp}, 68.73$

Leibowitza M.L., Liability Returns: A Mew Perspective on Asset Allocation, Salomon Brothers Inc., Bond Portfolio Analysis Group, New York, 1986.

Leibowilz, M.L., "Total Portfolio Duration A New Perspective on Asset Allocation", Financial Analyss' Journal, september/oktober 1986, pp. $19 \% 29$.

Leibowitz, M.L. en R.D. Henriksson, "Portfolio Optirnization Within a Surplus Framework: A New Perspective on Asset Allocation" ", Financial Analysis' Joumal, maari/april. 1988, pp. 43-51.

Lintner, $J_{t 3}$ "The Valuation of Risk Assets and the Selection of Risky Investments in Stock Portfolios and Capital Budgets", Review of Economies and Statistics "47, 1965, pp. 13-37.

Logue, D.E., "An Experiment in International Diversification", Journal of Portfolio Management. Fall 1982, pp. 222-27.

Loo, Van, P.D., "De Belegenggen van de Pensioenfondsen", Rotherdamse Monetcite Studies, 13. 1989.

Madura, J. en W. Reiff, "A Hedge Strategy for Intemational Portfolios". Journat of Portfolio Mangagentent, Fall 1985, pp. 70-74.

Markowiz, H.M., Porifolio Selection: Efficient Diversification of Investments. Yale University Press, New Haven, 1970.

Meer, van der, R.A.H., "Prakijk bij Pensioenfondsen" "VBA Seminar Matching, Kluwer Studiecentrum, 1989.

Meese, R.A. en K. Rogoff, "Emprical Excluarge Rate Modells of the Seventies: Do they Fit Out of Sample?", Journal of International Economics, 14, pp. 34.24. 
Mennis, E.A. J.L. Valentine en D.L. Mennis," New Perspectives on Pension Fund Management", Journal of Porifolio Wanagement, 7, nr. 3, 1981, pp. 46-50.

Ministerie van Financiën. Financièn Berichn, diwerse jaargangen.

Ministerie van Financièn, Persberichen nr, $87 / 203$ (10, juli 1987) en $89 / 165$ (16 jun 1989).

Ministerie van Financiêr, Wijziging won het Fscale Reginne voor Onderhoudswonzizhingen en Spaarvomen alsmede voor Verzekeraars en Pensioen/ichashev (Voonontwerp wan Wea), Den Hasas 10 juli 1987.

Ministerie van Financièn, Wijzigingen wan het Fiscale Reginte voor Onderhoudsvoorzieningen en Spadrwormen alsmede wan het Fiscafe Regime woor Verzekeradrs en Directiepensioen-fichames, 23 jumi 1989, Tweede Kamer, vergaderjaar 1988-1989, Kamerstuk 21198, Staatsuitgeverij, Den Haag.

Ministerie van Financiën, Regels Betreffende aen Heffing over Vernogevtsoverschoren vä Perwsioenfondsen (Wet op de Heffing over Vermogensower-schouten van Pensioenfondsen). Tweede Katmer, vergaderjaar 1988-1989, Kamerstuk 21 197, Staatsuitgeverij, Den Haag.

Ministerie van Financięn, Noka Beleggingswoorschriften, Tweede Kamer, zitting 1981, Kamerstuk 16963, Staatsuitgeverij, Den Haag.

MöhIman-Bronkhorst, M.J.M., "Een Pensionfonds op Weg naar de Volgende Reuw", Academisch Proefschriff, Universiteit Twente, 1988.

Pensioen- en Sparfondsenwet, Sociale Verzekeringswelten, Editie Kluwer, Deventer, 1989.

Pohlkamp, M.V.A.,, "Het Financieringsbeleid wan de Staat", Economisch Stotistische Berichten, 30 maart/6 april 1988 .

Rietworst, G.J.B., "Brede Herwaardering en de Levenswerzekeringsproducten", Tifdschrifo woo" Pensiaenuraagstukken, oktober 1987.

Rodenhuis, W. ." "Pensioen- en Lijfrentelichamen in het Voorontwerp Brede Herwatrdering", Tijdschrift woor Pensioenwragstukken, oktober 1987.

Rust, W.N.J., "Indexleningen", Economisch Statistische Berichten, 24 februari 1988.

Schaik, F, van, Equity-Bond Study, Barchays de Zoete Wedd, Londen, 1989.

Schouten, D.B.J. en A.H.J. Kolnaat, "Financieringsbedeid en Pensioenregelingen", Economisch Statisrische Berichten, 21 januari 1987.

SERO, Beleid en Beheer Pensioeven, diverse jastgangen.

Shaked, I., "International Equily Markets and the Investmelat Horizon", Journat of Porfolio Management, Winter 1985 , pp. 80-84.

Sharpe, W.F., "Capital Asset Prices: A Theory of Market Equilibrium under Conditions of Risk" " Joumal of Finance, 19, 1964, pp. 425-442.

Sociaal-Economisebe Raad, Advies Pensioenbesporingen, 's-Gravenhage, 1987.

Solnik, B., "Why Non Diversify Internationally rather than Domestically?", Financhal Analysirs" Journat, juli/augustus $1974, \mathrm{pp} .48-54$. 
Solnik. B.. Imernational Investments, Addison-Weslley, Reading, 1988.

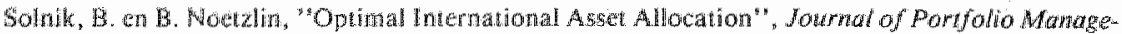
ment, Fall 1982, wp. 11-21.

Stevens, L.G.M. en P. wan Yperen, Kenpunten wan Pensioen, Kiwwer, Deventer, 1978.

Stevens, A.s "FS 87 Implications for Pension Plan Asset Allocation", Benafits and Compensathon tinternational, 17, an, $7,1988, \mathrm{pp} .7-11$.

Titman, S. en A. Warga "Stock Returns as Predictors of Interest Rates and Inflation" Journd of Financial and Quantirative Anolysis, 24, no, 1, 1989, pp. 47-58.

Toirkene, S.J., "Ministers en Bexuinigingen", Rotherdamse Manetaire Studies, nr. 36, 1989.

Tweedle Kamer, Hardefingen, diverse Jaurgangen, "s-Gravenhage, Statatsuitgeverij.

Van Klinken, J, cn A.J. Vernaat, "De Balans wark het Algemeen Burgerlijk Pensioenfonds", Economisch Statistische Berichten, 23 maant 1985.

Verbon, H.A.A., "Financieringstekort en Pensidenregelingen" "Economisch Statistische Berietlen, 21 januar 1987.

Verbon, H.A.A. en F.A.M.M. van Winden, Public Pensions and Political Pension-Making, De Economist, 133, no. 4, 1985, pp. 527-544.

Verbond van Verzekeraars in Nederland, Een Waardering yan de Brede Herwaardering, november 1987.

Verzekeringskamer, Vershg var de Verzekeringskamer, diverse jaren.

Verzekeringskamer, Finonciële Gegevens Pensioenfondsen, diverse jaren.

Woll, C.C.P., "Matching voor Pensioenfondsen: De Relatie ussen Beleggingsrendementen en Inflatie', Onderzoeksrapport, Faculteit der Economische Wetenschappen, Rijksuniversiteit Limburg, $1989 \mathrm{a}$.

Wolff "C.C.P. e.a "Wooronderzoek naar Toepassingen wan Computermodellen bij Vermogensbeheer door Pensioenfondsen" "Onderzoekrapport, Paculteit der Economische Wetenschappen, Rijksuniversiteil Limburgar, 19896.

Woll, C.C.P. "Time-Varying Parameters and the Out-of-Sample Forecasting Performance of Structural Exchange Rate Models", Joumal of Business and Economic Statistios, 5, no. 1, 1987. pp. 87.97 .

Wolf, C.C.P. "Exchange Rates, lnnovations and Forecasting", Journal of Internotionar Money and Finance, 7, no. 1, 1988a, pp. 49.61.

Woll, C.C.P., "Models of Exchange Rates: A Comparison of Forecasting Results", Internationat Jounat of Fopecasititg. 4, $1988 \mathrm{~b}, \mathrm{pp} .605$ 607. 